\title{
Detection of Early Intermediates of the Glycosylphosphatidylinositol anchor in Liquid-cultured Arabidopsis
}

\author{
Jong-Joo Cheong* · Hawk-Bin Kwon
}

Received: 28 August 2014 / Accepted: 29 September 2014 / Published Online: 31 March 2015

(C) The Korean Society for Applied Biological Chemistry 2015

\begin{abstract}
Tissue extracts were prepared from liquid-cultured Arabidopsis and reacted with UDP- $\left[{ }^{3} \mathrm{H}\right]$-GlcNAc. Phospholipid fractions were then extracted by butanol partitioning. Consecutive thin-layer chromatography identified two glycolipids sensitive to PI-specific phospholipase C, known as early intermediates in glycosylphosphatidylinositol anchor biosynthesis; phosphatidylinositol $\mathrm{N}$-acetylglucosamine and phosphatidylinositol glucosamine.
\end{abstract}

Keywords Arabidopsis $\cdot$ glycosylphosphatidylinositol anchor · liquid culture $\cdot$ thin-layer chromatography

\section{Introduction}

Many proteins within the eukaryotic cell surface are covalently linked to the plasma membrane through the glycosylphosphatidylinositol (GPI) anchor (Low, 1987; Udenfriend and Kodukula, 1995). Phosphatidylinositol (PI), a component of the membrane lipid bilayer, is sequentially connected to glucosamine (PI-GlcN), glycan (typically three mannoses), ethanolamine, and the carboxy terminus of a protein (Stevens, 1995; Takeda and Kinoshita, 1995). Phosphatidylinositol (PI)-specific bacterial phospholipase $\mathrm{C}$ (PI-PLC) can release GPI-anchored proteins (Lisanti and

\section{J.-J. Cheong}

Center for Food and Bioconvergence, Seoul National University, Seoul 151-921, Republic of Korea

\section{H.-B. Kwon}

Division of Biomedical Sciences, Sunmoon University, Asan 336-708, Republic of Korea

*Corresponding author (J.-J. Cheong: cheongjj@snu.ac.kr)

This is an Open Access article distributed under the terms of the Creative Commons Attribution Non-Commercial License (http://creativecommons. org/licenses/by-nc/3.0/) which permits unrestricted non-commercial use, distribution, and reproduction in any medium, provided the original work is properly cited.
Rodriguez-Boulan, 1990). In addition to a membrane attachment structure, the GPI anchor increases the lateral mobility of membrane proteins (Ishihara et al., 1987; Noda et al., 1987), a signal transduction mechanism of leukocytes (Robinson, 1991), and a sorting signal of apically expressed proteins in polarized epithelial cells (Lisanti and Rodriguez-Boulan, 1990; Brown and Rose, 1992). Deficiencies in GPI biosynthesis can lead to embryonic lethality in mammals (Kinoshita et al., 1997) and conditional lethality in eukaryotic microbes by blocking cell growth, division, and morphogenesis.

The first intermediate of GPI biosynthesis is PI- $\mathrm{N}$-acetylglucosamine (PI-GlcNAc), which results after transfer of GlcNAc from UDP-GlcNAc to PI (Kinoshita et al., 1997). The initial step is catalyzed by GPI- $N$-acetylglucosaminyltransferase. This enzyme was isolated from human cells and has been shown to consist of at least six subunits: PIG-A, PIG-C, PIG-H, GPI-1, PIG-P, and DPM2 (Ikezawa, 2002). The PI-GlcNAc form is deacetylated subsequently by PIG-L to yield PI-GlcN.

It has been reported that the Arabidopsis SETH1 and SETH2 genes encode homologs of $P I G-C$ and $P I G-A$, respectively (Lalanne et al., 2004). Mutations within these two genes specifically block pollen germination and tube growth. The Arabidopsis PNT1 gene encodes a homolog of mammalian PIG-M, an endoplasmic reticulum-localized mannosyltransferase (Gillmor et al., 2005). In addition, the $O s P I G-F$ gene that encodes a homolog of human PIG-F, a subunit of the GPI anchor phosphoethanolamine transferase complexes, was identified in rice (Lee and Kang, 2008). In studies on preassembly of the GPI anchor in mammalian cells, cell-free extracts were incubated with UDP $\left[{ }^{3} \mathrm{H}\right]-\mathrm{GlcNAc}$ (Hirose et al., 1991; Miyata et al., 1993), and the resulting phospholipid products were analyzed by thin-layer chromatography (TLC).

Plant tissues contain high concentrations of various lipids, cutin, and waxes, which hamper the detection of PI-containing molecules on the TLC plate. In the study described herein, tissue extracts prepared from liquid-cultured Arabidopsis were used to detect PI-GlcNAc and PI-GlcN. We believe that the procedure 
described in this study will be useful for the purification of GPI$\mathrm{N}$-acetylglucosaminyltransferase, which catalyzes the initial step in GPI-anchor biosynthesis in plants.

\section{Materials and Methods}

Culture of Arabidopsis. For liquid culture of Arabidopsis, the seed (ecotype Columbia) surface was sterilized with $70 \%$ ethanol for $2 \mathrm{~min}, 0.5 \% \mathrm{NaOCl} / 0.5 \%$ sodium dodecyl sulfate for $15 \mathrm{~min}$, and rinsed five times with sterilized water. Approximately 50 seeds were germinated and grown for 3 weeks in culture medium in a shaking incubator at $22^{\circ} \mathrm{C}, 100 \mathrm{rpm}$, under a 16 -h-light/8-hdark cycle. The medium contained $1 \times$ MS salt mixture $(J R H$ Biosciences, USA), $1 \%$ sucrose, vitamins ( $1 \mathrm{mg} / \mathrm{mL}$ thiamine$\mathrm{HCl}, 0.5 \mathrm{mg} / \mathrm{mL}$ phyridoxine- $\mathrm{HCl}$, and $0.5 \mathrm{mg} / \mathrm{mL}$ nicotinic acid), $100 \mathrm{mg} / \mathrm{mL}$ inositol, and $0.5 \mathrm{~g} / \mathrm{L}$ MES. The $\mathrm{pH}$ was adjusted to 5.7 with $1 \mathrm{~N} \mathrm{KOH}$.

Tissue extracts. Liquid-cultured Arabidopsis was ground with glass beads using a mortar according to a procedure described previously (Hirose et al., 1991). The mixture was filtered through two layers of Miracloth, and centrifuged at $200,000 \times g$ at $4^{\circ} \mathrm{C}$ for $20 \mathrm{~min}$. The pellet was washed briefly with extraction buffer (1 $\mathrm{mL} / 1 \mathrm{~g}$ tissue) containing $50 \mathrm{mM}$ Na-HEPES, pH 7.4, $25 \mathrm{mM}$ $\mathrm{KCl}, 5 \mathrm{mM} \mathrm{MgCl}_{2}, 2 \mathrm{mM}$ dithiothreitol, $1 \mathrm{mM}$ phenylmethylsulfonyl fluoride dissolved in ethanol, $1 \mathrm{mM}$ ethylene glycol tetraacetic acid, and a protease inhibitor cocktail containing $10 \mu \mathrm{g} /$ $\mathrm{mL}$ pepstatin (in methanol), $5 \mu \mathrm{g} / \mathrm{mL}$ aprotinin, $5 \mu \mathrm{g} / \mathrm{mL}$ leupeptin and $10 \mu \mathrm{g} / \mathrm{mL} \alpha_{2}$-macroglobulin, resuspended $(0.5 \mathrm{~mL} / \mathrm{g}$ tissue), and stored at $-80^{\circ} \mathrm{C}$ until use.

PI-GlcNAc labeling reaction. For the PI-GlcNAc labeling reaction, $100 \mu \mathrm{L}(10 \mu \mathrm{Ci})$ of UDP $\left[{ }^{3} \mathrm{H}\right]$-GlcNAc (Dupont) were placed in an Eppendorf tube and dried using a speed vacuum for $1 \mathrm{~h}$. Tissue extracts $(195 \mu \mathrm{L})$ were thawed and added to each tube in addition to $0.2 \mu \mathrm{g} / \mathrm{mL}$ tunicamycin $(2 \mu \mathrm{L}$ of $0.02 \mathrm{mg} / \mathrm{mL}$ stock), $5 \mathrm{mM} \mathrm{MnCl}$ ( $1 \mu \mathrm{L}$ of $1 \mathrm{M}$ stock) and $1 \mathrm{mM}$ adenosine triphosphate (ATP; $2 \mu \mathrm{L}$ of $100 \mathrm{mM}$ stock). Next, reaction mixtures were incubated at $37^{\circ} \mathrm{C}$ for $15 \mathrm{~min}$ and terminated by the addition of $1.3 \mathrm{~mL}$ chloroform:methanol $(1: 1, \mathrm{v} / \mathrm{v})$. Reaction mixtures were then centrifuged using a microfuge table-top centrifuge, and supernatants were dried under vacuum. Residues were partitioned in water-saturated 1-butanol:water ( $200 \mu \mathrm{L}$ each). Upper solutions were removed and dried, and dissolved in $10 \mu \mathrm{L}$ chloroform: methanol $(2: 1, \mathrm{v} / \mathrm{v})$.

PI-PLC digestion. Sample materials were stirred vigorously after adding $100 \mu \mathrm{L}$ Tris-acetate buffer, $\mathrm{pH} 7.4$, and $0.1 \%$ sodium cholate. Next, $10 \mu \mathrm{L}$ of $0.5 \mathrm{U} / \mu \mathrm{L}$ PI-PLC (Sigma-Al drich, USA), or sterilized water were added to the tubes. Tubes added with water or PI-PLC (at $30^{\circ} \mathrm{C}$ ) were incubated for $4 \mathrm{~h}$.

TLC. Reaction products were analyzed by TLC using a silica gel 60 plate (Merck, USA), after developing with chloroform: methanol: $1 \mathrm{M} \mathrm{NH}_{4} \mathrm{OH}(10: 10: 3, \mathrm{v} / \mathrm{v})$ for $1 \mathrm{~h}$. Radioactive spots were detected using EN ${ }^{3} \mathrm{HANCE}$ spray (New England BioLabs) and exposed to X-ray film for $20 \mathrm{~h}$.

\section{Results and Discussion}

Flurography and autoradiography analyses revealed two spots representing PI-GlcNAc $(\mathrm{Rf}=0.76)$ and PI-GlcN $(\mathrm{Rf}=0.70)$ on the TLC plate (Fig. 1), as identified in an experiment with human JY cells (Miyata et al., 1993), from liquid-cultured Arabidopsis tissue extract.

We repeated this experiment with tissue extract from maize coleoptiles, which exhibited three or four bands on the plate (data

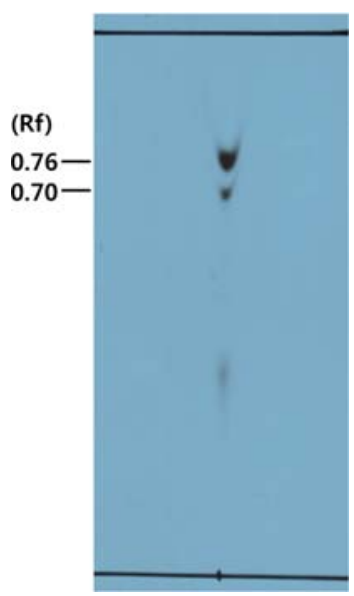

Fig. 1 Detection of early intermediates of the glycosylphosphatidylinositol anchor in liquid-cultured Arabidopsis. For PI-GlcNAc labeling, tissue extracts were first reacted with UDP $\left[{ }^{3} \mathrm{H}\right]$-GlcNAc. Residues were then partitioned in water-saturated $n$-butanol: water. Upper solutions were removed and dried, dissolved in chloroform: methanol $(2: 1, \mathrm{v} / \mathrm{v})$, and analyzed TLC using silica gel plates. Chloroform: methanol: $1 \mathrm{M} \mathrm{NH}_{4} \mathrm{OH}$ $(10: 10: 3, \mathrm{v} / \mathrm{v})$ was used to develop TLC plates. Radioactive spots were detected using $\mathrm{EN}^{3} \mathrm{HANCE}$ spray and then exposed to X-ray film. Two spots representing PI-GlcNAc $(\mathrm{Rf}=0.76)$ and $\mathrm{PI}-\mathrm{GlcN}(\mathrm{Rf}=0.70)$ were appeared on the TLC plate.

\section{B PI-PLC}

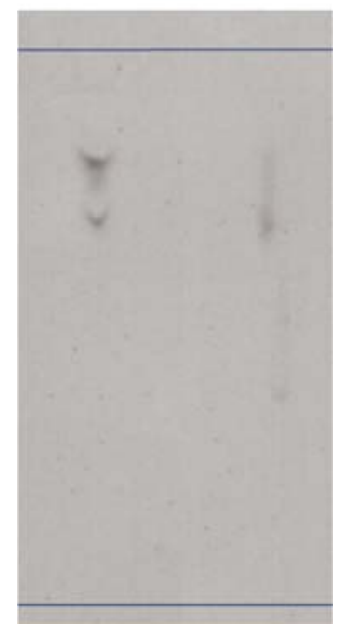

Fig. 2 Phospholipase sensitivity of glycosylphosphatidylinositol spots on TLC plates. Silica powder in the area between Rf $0.6-0.9$ on the silica plate (Fig. 1) was excised with a blade and extracted with $n$-butanol. The extract was then reacted with buffer (B) only or PI-specific phospholipase C (PI-PLC), respectively, and developed on TLC plates. Two spots represent PI-GlcNAc $(\mathrm{Rf}=0.76)$ and PI-GlcN $(\mathrm{Rf}=0.70)$, respectively. 
not shown). Migration of the products was dependent on the amount of sample loaded on the plate, implying an unidentified interaction between the compounds and the developing solvent.

We also examined the sensitivity of the two Arabidopsis glycolipids from the TLC plate to PI-PLC. The two glycolipids in the area between $\mathrm{Rf} 0.6-0.9$ on the silica plate were excised with a blade. TLC and fluorography revealed that the two compounds were sensitive to PI-PLC, thereby revealing their identities as PIGlcNAc and PI-GlcN, respectively (Fig. 2).

Arabidopsis is a model plant for molecular biology and genomics studies. However, in general, this plant has been regarded as a poor source for biochemical analysis. This is likely because the tissues contain high concentrations of various lipids, cutin, and waxes. In contrast, the procedure described in this study will facilitate the purification of enzyme(s) that catalyze the first step in GPI-anchor biosynthesis in plants, thus representing a direct connection to the genomic information accumulated in the extensive studies conducted using this plant model.

Acknowledgment This work was supported by the Basic Science Research Program through the National Research Foundation (Grant number NRF-2013R1A1A2009266), by the Technology Development Program for Life Industry through the Korea Institute of Planning and Evaluation for Technology of Food, Agriculture, Forestry and Fisheries (Grant number 111076-5), and by the Next Generation BioGreen 21 Research Program through the National Center for GM Crops of the Rural Development Administration (to H-B Kwon).

\section{References}

Brown DA and Rose JK (1992) Sorting of GPI-anchored proteins to glycolipid-enriched membrane subdomains during transport to the apical cell surface. Cell 68, 533-44.

Gillmor CS, Lukowitz W, Brininstool G, Sedbrook JC, Hamann T, Poindexter $\mathrm{P}$ et al. (2005) Glycosylphosphatidylinositol-Anchored Proteins Are Required for Cell Wall Synthesis and Morphogenesis in Arabidopsis. Plant Cell 17, 1128-40.

Hirose S, Ravi L, Hazra SV, and Medorf ME (1991) Assembly and deacetylation of $N$-acetylglucosaminyl-plasmanylinositol in normal and affected paroxysmal nocturnal hemoglobinuria cells. Proc Natl Acad Sci USA 88, 3762-6.

Ikezawa H (2002) Glycosylphosphatidylinositol (GPI)-anchored proteins. Biol Pharm Bull 25, 409-17.

Ishihara A, Hou Y, and Jacobson K (1987) The Thy-1 antigen exhibits rapid lateral diffusion in the plasma membrane of rodent lymphoid cells and fibroblasts. Proc Natl Acad Sci USA 84, 1290-3.

Kinoshita T, Ohishi K, and Takeda J (1997) GPI-anchor synthesis in mammalian cells: genes, their Products, and a deficiency. J Biochem 122, 251-7.

Lalanne E, Honys D, Johnson A, Borner GHH, Lilley KS, Dupree P et al. (2004) SET1 and SET2, two components of the glycosylphosphatidylinositol anchor biosynthetic pathway, are required for pollen germination and tube growth in Arabidopsis. Plant Cell, 16, 229-40.

Lee DH and Kang SG (2008) Characterization of phosphatidylinositol-glycan biosynthesis protein class F gene in rice. DNA Seq 19, 282-90.

Lisanti MP and Rodriguez-Boulan E (1990) Glycophospholipid membrane anchoring provides clues to the mechanism of protein sorting in polarized epithelial cells. Trends Biochem Sci 15, 113-8.

Low MG (1987) Biochemistry of the glycosyl-phosphatidylinositol membrane protein anchors. Biochem $J$ 244, 1-13.

Miyata T, Takeda J, Iida Y, Yamada N, Inoue N, Takahashi M et al. (1993) Science 259, 1318-20.

Noda M, Yoon K, Rodan GA, and Koppel DE (1987) High lateral mobility of endogenous and transfected alkaline phosphatase: a phosphatidylinositolanchored membrane protein. J Cell Biol 105, 1671-7.

Robinson PJ (1991) Signal transduction by GPI-anchored membrane proteins. Cell Biol Int Rep 15, 761-7.

Stevens VL (1995) Biosynthesis of glycosylphosphatidylinositol membrane anchors. Biochem J 310, 361-70.

Takeda J and Kinoshita T (1995) GPI-anchor biosynthesis. Trends Biochem Sci 20, 367-71.

Udenfriend S and Kodukula K (1995) How glycosylphosphatidylinositolanchored proteins are made. Аппи Rev Biochem 64, 563-91. 